\title{
Nocardia amarae sp. nov., an Actinomycete Common in Foaming Activated Sludge
}

\author{
MARY P. LECHEVALIER and H. A. LECHEVALIER
}

\begin{abstract}
Institute of Microbiology, Rutgers University, The State University of New Jersey,
\end{abstract} New Brunswick, New Jersey 08903

\begin{abstract}
One hundred and seven strains of nocardiae have been isolated from samples of activated sludge or from foam forming on activated sludge coming from 10 sewage-treatment plants in five states. Thirty-five of these strains belong to a previously undescribed species containing a novel type of nocardomycolic acid whose $\alpha$ branch is mono-unsaturated. The name proposed for this new species is Nocardia amarae. The type strain is IMRU W3960 (= ATCC 27808).
\end{abstract}

Numerous filamentous organisms have been reported to be present in activated sludge (2, 3 ), but actinomycetes are only rarely mentioned $(20,21)$. At times, activated-sludge sewage-treatment plants are plagued with the production of a viscous scum or foam (24). Microscope examination of such foams revealed that they may be composed of a mass of actinomycetic hyphae (R. F. Lewis, personal communication). We have examined a number of foam samples from plants in New Jersey, New York, Florida, Virginia, and Texas and have found that the most common actinomycete present was a nocardia which does not correspond to any described species known to us. The purpose of this paper is to describe and name this new organism.

\section{MATERIALS AND METHODS}

Bacterial strains. The strains included in this study are listed in Table 1.

Isolation of cultures. Samples of sewage foam, either shipped to us in dry ice by air express or collected locally, were diluted (wt/vol) in sterile distilled water, and appropriate dilutions were plated out by pipetting $0.1 \mathrm{ml}$ onto the surface of previously poured and solidified agar plates, and by spreading with a sterile glass spreader. The media most useful in isolating the actinomycetes were yeast extract-Czapeks (YCZ) (12), Glycerol Agar (GA) (11), or potatodextrose agar (PDA)-300 g of peeled old potatoes were cooked in tap water until soft and filtered. The extract was made up to 1 liter, and $15 \mathrm{~g}$ of agar and 20 $\mathrm{g}$ of dextrose were added. The $\mathrm{pH}$ was not adjusted. The medium was autoclaved at $15 \mathrm{lbs}$ for $20 \mathrm{~min}$. Incubation of plates was carried out for 10 days at 28 C. Many other common bacteriological media which were examined did not support good growth of $N$. amarae on isolation plates.

Maintenance of cultures. Cultures were maintained on yeast extract dextrose (YD) (23) or YCZ slants.
Physiological tests. The tests employed were those of Gordon and Mihm (9) and Gordon (5, 7). Phosphatase production was estimated according to the method of Barber and Kuper (1), and growth on $5 \% \mathrm{NaCl}$ in $\mathrm{YD}$ agar according to the method of Goodfellow (4).

Cell-wall and whole-cell analyses. Cell-wall analyses were made according to the method described by Suput et al. (22), and whole-cell analyses according to the procedure described by Lechevalier (15).

Mycolic-acid analyses. Mycolic acids were isolated according to the method of Lechevalier et al. $(16,19)$. The unsaturation in the $\alpha$ branch of the nocardomycolates from the strains studied was verified by the retention times of the pyrolysis fragments not only on OV-1 columns as above but also on $15 \%$ DEGS columns (60/80 chromosorb W, AW, DMCS) and by the reaction of the mycolates by using a modified solvomercuration-demercuration technique (18). In this reaction, the elements of methanol are added across a double bond, and the resulting monomethoxy derivative elutes later than the starting compound. The modified procedure is as follows. To $5 \mathrm{mg}$ of methyl nocardomycolate solubilized in 1 to 2 drops of methylene chloride are added $10 \mathrm{mg}$ of $\mathrm{Hg}(\mathrm{OAc})_{2}$ in 1 $\mathrm{ml}$ of methanol. After $18 \mathrm{~h}$ at $23 \mathrm{C}, 1.5 \mathrm{ml}$ of $15-\mathrm{mg}$ $\mathrm{NaBH}_{4}$ in $1 \% \mathrm{NaHCO}_{3}$ are added. After standing $1 \mathrm{~h}$ to coagulate the precipitated mercury, the supernatant is extracted with one half its volume of methylene chloride. The extract is examined by gas chromatography as previously described, the derivatized nocardomycolates giving rise to mono-methoxy pyrolysis fragments whose retention times are compared to authentic mono-methoxy fatty esters prepared in the same way.

Electron microscopy. The surface of a 1-week-old culture of strain Se 149B on YD agar was covered with a $1-\mathrm{mm}$ layer of $2 \%$ water agar. After solidification, cubes with a small colony in the center were cut and placed in double aldehyde fixative ( $1 \%$ glutaraldehyde and $1.5 \%$ paraformaldehyde in $0.1 \mathrm{M}$ phosphate buffer) for $30 \mathrm{~min}$ at room temperature. After washing in phosphate buffer, then in Veronal acetate buffer, secondary fixation was accomplished by placing the cubes overnight in the dark in $1 \%$ osmium 
TABLE 1. Sources of strains used in this study

\begin{tabular}{|c|c|c|}
\hline $\begin{array}{c}\text { Strain } \\
\text { designation }^{a}\end{array}$ & Identity & Source \\
\hline SN 5101 & Nocardia rhodochrous $b$ & R. Bonicke \\
\hline SN 5104 & Nocardia rhodochrous $b$ & R. Bonicke \\
\hline A 12974 & Nocardia rhodochrous & R. E. Gordon \\
\hline I 3639 & Nocardia rhodochrous ${ }^{c}$ & R. E. Gordon \\
\hline I 1240 & Nocardia rhodochrous ${ }^{c}$ & R. E. Gordon \\
\hline NC 8139 & Nocardia rhodochrous ${ }^{c}$ & R. E. Gordon \\
\hline I $1082 S$ & Nocardia rhodochrous $\mathrm{c}$ & R. E. Gordon \\
\hline I 624 & Nocardia rhodochrous ${ }^{c}$ & R. E. Gordon \\
\hline I 369 & Nocardia rhodochrous ${ }^{c}$ & R. E. Gordon \\
\hline I 462 & Nocardia rhodochrous ${ }^{c}$ & R. E. Gordon \\
\hline I 515 & Nocardia rhodochrous ${ }^{c}$ & R. E. Gordon \\
\hline I 570 & Nocardia rhodochrous ${ }^{c}$ & R. E. Gordon \\
\hline I 625 & Nocardia rhodochrous ${ }^{c}$ & R. E. Gordon \\
\hline N 10 & Nocardia rhodochrous & M. Goodfellow \\
\hline N 31 & Nocardia rhodochrous & M. Goodfellow \\
\hline N 60 & Nocardia rhodochrous & M. Goodfellow \\
\hline N 239 & Nocardia rhodochrous & M. Goodfellow \\
\hline NC 1621 & Strain related to $N$. rhodochrous ${ }^{d}$ & R. E. Gordon \\
\hline A 7005 & Strain related to $N$. rhodochrous & R. E. Gordon \\
\hline A 11890 & Strain related to $N$. rhodochrous & R. E. Gordon \\
\hline I 384 & Strain related to $N$. rhodochrous ${ }^{d}$ & R. E. Gordon \\
\hline I 549 & Strain related to $N$. rhodochrous ${ }^{d}$ & R. E. Gordon \\
\hline I 564 & Strain related to $N$. rhodochrous & R. E. Gordon \\
\hline I 1256 & Strain related to $N$. rhodochrous $s^{d}$ & R. E. Gordon \\
\hline Mil 14 & N. rhodochrous & Abnormal foam, Milwaukee, Wis., R. F. Lewis \\
\hline Mil 15 & N. rhodochrous & Abnormal foam, Milwaukee, Wis., R. F. Lewis \\
\hline SJ 2 & N. rhodochrous & Abnormal foam, San José, Calif., R. F. Lewis \\
\hline Se 113 & N. rhodochrous & Abnormal foam, Delran, N. J. \\
\hline Se 135 & N. rhodochrous & Abnormal foam, Middletown, N. J. \\
\hline Se 141 & $N$. rhodochrous & Abnormal foam, Ocean Township, N. J. \\
\hline Se 167 & N. rhodochrous & Abnormal foam, Hartford, Conn. \\
\hline Se 187 & $N$. rhodochrous & Abnormal foam, Hartford, Conn. \\
\hline Se 188 & $N$. rhodochrous & Abnormal foam, Hartford, Conn. \\
\hline Se 189 & $N$. rhodochrous & Abnormal foam, Bordentown, N. J. \\
\hline Se 192 & $N$. rhodochrous & Abnormal foam, Bordentown, N. J. \\
\hline Se 194 & $N$. rhodochrous & Abnormal foam, Bordentown, N. J. \\
\hline Se 3 & Nocardia amarae & Abnormal foam, Andover (Miami), Fla. \\
\hline Se 6 & Nocardia amarae & Abnormal foam, Andover (Miami), Fla. \\
\hline Se 45 & Nocardia amarae & Abnormal foam, Andover (Miami), Fla. \\
\hline Se 51 & Nocardia amarae & Abnormal foam, Riverdale (Miami), Fla. \\
\hline Se 53 & Nocardia amarae & Abnormal foam, Riverdale (Miami), Fla. \\
\hline Se 61 & Nocardia amarae & Abnormal foam, Ocean Township, N. J. \\
\hline Se 64 & Nocardia amarae & Abnormal foam, Ocean Township, N.J. \\
\hline Se 65 & Nocardia amarae & Abnormal foam, Ocean Township, N. J. \\
\hline Se 85 & Nocardia amarae & Abnormal foam, Austin, Tex. \\
\hline Se 87 & Nocardia amarae & "Normal" froth, Austin, Tex. \\
\hline Se 90 & Nocardia amarae & Abnormal foam, Austin, Tex. \\
\hline Se 91 & Nocardia amarae & Abnormal foam, Austin, Tex. \\
\hline Se 96 & Nocardia amarae & Sludge return, Austin, Tex. \\
\hline Se 97 & Nocardia amarae & Abnormal foam, Bordentown Township, N. J. \\
\hline Se 102 & Nocardia amarae & Abnormal foam, Bordentown Township, N. J. \\
\hline Se 106 & Nocardia amarae & Abnormal foam, Eversham, N. J. \\
\hline Se 107 & Nocardia amarae & Abnormal foam, Eversham, N. J. \\
\hline Se 110 & Nocardia amarae & Abnormal foam, Delran, N. J. \\
\hline Se 111 & Nocardia amarae & Abnormal foam, Delran, N. J. \\
\hline Se 117 & Nocardia amarae & Abnormal foam, Matawan, N. J. \\
\hline
\end{tabular}


TABLE 1.-(Cont'd.)

\begin{tabular}{|c|c|c|}
\hline $\begin{array}{c}\text { Strain } \\
\text { designation }\end{array}$ & Identity & Source \\
\hline Se 118 & Nocardia amarae & Abnormal foam, Matawan, N. J. \\
\hline Se 119 & Nocardia amarae & Abnormal foam, Matawan, N. J. \\
\hline Se 120 & Nocardia amarae & Abnormal foam, Matawan, N. J. \\
\hline Se 122 & Nocardia amarae & Artificial foam lab isolate, Bordentown, N. J. \\
\hline Se 139 & Nocardia amarae & Abnormal foam, Ocean Township, N. J. \\
\hline Se 144 & Nocardia amarae & Abnormal foam, Ocean Township, N. J. \\
\hline Se 149 & Nocardia amarae & Abnormal foam, Jamaica Bay, N. Y. \\
\hline Se 149B & Nocardia amarae & Abnormal foam, Jamaica Bay, N. Y. \\
\hline Se 151 & Nocardia amarae & Abnormal foam, Jamaica Bay, N. Y. \\
\hline Se 154 & Nocardia amarae & Abnormal foam, Jamaica Bay, N. Y. \\
\hline Se 156 & Nocardia amarae & Sample no. 1 , abnormal foam, Arlington, Va. \\
\hline Se 157 & Nocardia amarae & Sample no. 1 , abnormal foam, Arlington, Va. \\
\hline Se 160 & Nocardia amarae & Sample no. 1 , abnormal foam, Arlington, Va. \\
\hline Se 162 & Nocardia amarae & Sample no. 2 , abnormal foam, Arlington, Va. \\
\hline Se 164 & Nocardia amarae & Sample no. 2 , abnormal foam, Arlington, Va. \\
\hline
\end{tabular}

${ }^{a}$ A, American Type Culture Collection, Rockville, Md.; I, Institute of Microbiology, Rutgers University: NC, National Collection of Type Cultures, London, England; N. Collection of the University of Newcastle Upon Tyne (England).

${ }^{b}$ Received as $N$. pellegrini.

${ }^{c}$ Received as "Mycobacterium" rhodochrous.

${ }^{d}$ Received as related to "Mycobacterium" rhodochrous.

tetroxide in Veronal-acetate buffer containing $0.1 \%$ tryptone and $0.05 \%$ sodium chloride. After washing in buffer and dehydrating in ethanol, the cubes were transferred to propylene oxide and were then placed in a $50 \%$ propylene oxide-50\% DER332-732 mixture for $1 \mathrm{~h}$ at $45 \mathrm{C}$. After $1 \mathrm{~h}$ at $37 \mathrm{C}$ in pure resin, the cubes were placed in capsules containing the same resin. Curing of the resin was carried out for $14 \mathrm{~h}$ at $37 \mathrm{C}$, then $24 \mathrm{~h}$ at $45 \mathrm{C}$ followed by $24 \mathrm{~h}$ at $60 \mathrm{C}$. Sections 5,000 to $7,000 \mathrm{~nm}$ thick were cut on a Sorvall MT-1 microtome with a diamond knife and stained by immersion for $30 \mathrm{~min}$ in Reynold's lead citrate. The electron microscope used was a JEM 120 operated at $80 \mathrm{kV}$.

\section{RESULTS AND DISCUSSION}

Samples of foam and sludge from activatedsludge sewage-treatment plants were received from two localities in the Miami, Fla., area (Riverdale and Andover), Arlington, Va., and Austin, Tex. Similar samples were collected in Ocean, Bordentown, Evesham, Delran, and Matawan Townships in N.J., and Jamaica Bay, N.Y. All of these samples were found to be rich in actinomycetic hyphae when examined by phase-contrast microscopy.

Foaming problems appeared at first to be limited to seasons or areas where the average temperature of the water was $>55 \mathrm{C}$. Recently, however, some northern plants have been experiencing this problem at lower temperatures.

All of the strains of the new organism had a cell wall of type IV (17) and a whole-cell sugar pattern of type A (15), typical of members of the genus Nocardia. Other genera having this type of cell wall include Pseudonocardia, Mycobacterium, Corynebacterium (diphtheriae type), Micropolyspora, and Saccharomonospora. They contained nocardomycolic acids (16) of a novel type whose main $\alpha$ branch is mono-unsaturated. Thus, the mycolates of these strains give rise, on pyrolysis, to major amounts of mono-unsaturated fatty esters having 16 and 18 carbons, accompanied for some strains by minor amounts of analogous saturated fragments. This is in contrast to most Nocardia strains we have examined to date which contain nocardomycolates whose pyrolysis fragments are saturated fatty esters having 12 to 18 carbons. Nevertheless, minor amounts of unsaturated fragments have been noted in the pyrolysates of the mycolic acids of numerous nocardiae, particularly members of the $N$. rhodochrous group (M. P. Lechevalier, unpublished results). We have also found this novel type of nocardomycolate in two other nocardial strains: $N$. vaccinii IMRU 3500 and $N$. carnea 3419. It has been reported (13) that corynomycolates isolated from the free lipids and cord factor of a strain of Nocardia asteroides contained mono-unsaturated $\alpha$ branches. Conventional nocardomycolic acids having a saturated $\alpha$ branch were found in the wall-bound lipids of this strain. We have 
TABLE 2. A comparison of the physiological characteristics of $N$. amarae with other species of Nocardia

\begin{tabular}{|c|c|c|c|c|}
\hline Determination & $\begin{array}{l}\text { N. amarae } \\
\text { (35 strains) }\end{array}$ & $\begin{array}{l}\text { N. asteroides } \\
\left(137 \text { strains }^{a}\right)\end{array}$ & $\begin{array}{c}\text { N. brasiliensis } \\
\left(62 \text { strains }^{a}\right)\end{array}$ & $\begin{array}{c}N . \text { caviae } \\
\left(24 \text { strains }^{a}\right)\end{array}$ \\
\hline \multicolumn{5}{|l|}{ Hydrolysis of: } \\
\hline $\begin{array}{l}\text { Casein } \\
\text { Hypoxanthine }\end{array}$ & $\begin{array}{l}0^{\circ} \\
0\end{array}$ & $\begin{array}{l}0 \\
4\end{array}$ & $\begin{array}{l}98 \\
94\end{array}$ & $\begin{array}{r}0 \\
100\end{array}$ \\
\hline Tyrosine & 0 & 1 & 100 & 0 \\
\hline Xanthine & 0 & 0 & 0 & 100 \\
\hline Adenine & 0 & 0 & 3 & 4 \\
\hline Starch & $86(w)$ & 67 & 55 & 54 \\
\hline Gelatin & 0 & $34^{c}$ & & \\
\hline Esculin & 100 & 100 & 100 & 100 \\
\hline Urea & 100 & 96 & 100 & 92 \\
\hline \multicolumn{5}{|l|}{ Production of: } \\
\hline Nitrate reductase & 100 & 86 & 90 & 100 \\
\hline \multicolumn{5}{|l|}{ Growth at/on/in: } \\
\hline $10 \mathrm{C}(\mathrm{YD})$ & 6 & 15 & 37 & 13 \\
\hline $45 \mathrm{C}(\mathrm{YD})$ & 0 & 41 & 2 & 50 \\
\hline Lysozyme broth & 9 & 100 & 100 & 100 \\
\hline \multicolumn{5}{|l|}{ Acid from: } \\
\hline Adonitol & 0 & 0 & 0 & 0 \\
\hline Arabinose & 0 & 0 & 0 & 4 \\
\hline Dulcitol & 0 & 0 & 0 & 0 \\
\hline Erythritol & 0 & 7 & 2 & 0 \\
\hline Galactose & 0 & 27 & 94 & 0 \\
\hline Glucose & 100 & 98 & 97 & 100 \\
\hline Glycerol & 100 & $99^{d}$ & $98^{d}$ & $100^{d}$ \\
\hline Inositol & 92 & 3 & 100 & 100 \\
\hline Lactose & 0 & 0 & 0 & 0 \\
\hline Maltose & 100 & 6 & 4 & 18 \\
\hline Mannitol & 100 & 1 & 94 & 90 \\
\hline Mannose & 100 & 17 & 68 & 36 \\
\hline Melibiose & 0 & & & 0 \\
\hline$\alpha$-Methyl-D-glucoside & 0 & 0 & 0 & 0 \\
\hline Raffinose & 0 & 0 & 0 & 0 \\
\hline Rhamnose & 92 & 32 & 0 & 5 \\
\hline Salicin & 100 & $25^{c}$ & & \\
\hline Sorbitol & 0 & 0 & 0 & 0 \\
\hline Xylose & 0 & 0 & 0 & 5 \\
\hline \multicolumn{5}{|l|}{ Utilization of: } \\
\hline Acetate & 100 & $100^{d}$ & $100^{d}$ & $100^{d}$ \\
\hline Benzoate & 0 & $0^{d}$ & $2^{d}$ & $0^{d}$ \\
\hline Citrate & 0 & 38 & 98 & 29 \\
\hline Lactate & 100 & $31^{e}$ & & \\
\hline Malate & 100 & 97 & 100 & 100 \\
\hline Oxalate & 0 & $0^{e}$ & & \\
\hline Propionate & 100 & $100^{d}$ & $100^{d}$ & $100^{d}$ \\
\hline Pyruvate & 100 & $99^{d}$ & $100^{d}$ & $100^{d}$ \\
\hline Succinate & 100 & 92 & 100 & 100 \\
\hline \multicolumn{5}{|l|}{ Survival: } \\
\hline $50 \mathrm{C} / 8 \mathrm{~h}$ & 0 & 94 & 0 & 88 \\
\hline
\end{tabular}

${ }^{a}$ Gordon and Horan (8).

$b$ Percent positive; w, weak.

${ }^{c}$ Gordon and Mihm (9) (79 strains of $N$. asteroides).

${ }^{d}$ Gordon and Mihm (10) (142 strains of $N$. asteroides; 15 strains of $N$. caviae; 62 strains of $N$. brasiliensis).

${ }^{e}$ R. E. Gordon, personal communication to M.P.L.

obtained this organism through the kindness of J. Rozanis but have found only normal nocardomycolates in its free and bound lipids. Under our conditions of growth, it is possible that the percentage of the corynomycolates in the mycolate fractions is too low to be detected.

F. Mariat, of the Institut Pasteur, in Paris, 


\begin{tabular}{|c|c|c|c|c|c|c|c|c|}
\hline \multirow[b]{2}{*}{ Determination } & \multirow{2}{*}{$\begin{array}{c}\text { N. amarae } \\
\text { (35 } \\
\text { strains) }\end{array}$} & \multicolumn{2}{|c|}{ N. rhodochrous } & \multicolumn{2}{|c|}{$\begin{array}{l}\text { Nocardia sp. } \\
\text { related to } \\
\text { N. rhodochrous }\end{array}$} & \multirow{2}{*}{$\begin{array}{l}N . \text { rhodo- } \\
\text { chrous } \\
\\
\text { (sewage) } \\
\text { (12 } \\
\text { strains) }^{b}\end{array}$} & \multirow{2}{*}{$\begin{array}{c}\text { N. vac- } \\
\text { cinii } \\
\\
\text { IMRU } \\
3500^{b}\end{array}$} & \multirow{2}{*}{$\begin{array}{c}N . \\
\text { carnea } \\
\text { IMRU } \\
3419^{b}\end{array}$} \\
\hline & & $\begin{array}{c}(97 \\
\text { strains) }\end{array}$ & $\begin{array}{c}(17 \\
\text { strains) }\end{array}$ & $\begin{array}{c}(36 \\
\text { strains })^{a}\end{array}$ & $\stackrel{(7}{\text { strains }^{b}}$ & & & \\
\hline \multicolumn{9}{|l|}{ Hydrolysis of: } \\
\hline Casein & $0^{c}$ & 0 & & 0 & & 0 & - & - \\
\hline Hypoxanthine & 0 & & 0 & & 0 & 0 & - & - \\
\hline Tyrosine & 0 & 74 & & 5 & & 58 & - & - \\
\hline Xanthine & 0 & 0 & & 0 & & 0 & - & - \\
\hline Adenine & 0 & & 35 & & 71 & 75 & - & - \\
\hline Starch & $86(w)^{d}$ & 97 & 35 & 97 & 43 & 25 & - & - \\
\hline Gelatin & 0 & & 0 & & 0 & 0 & - & - \\
\hline Esculin & 100 & & 76 & & 86 & 75 & + & + \\
\hline Urea & 100 & $73^{e}$ & & & 100 & 83 & + & - \\
\hline \multicolumn{9}{|l|}{ Production of: } \\
\hline Phosphatase & $83^{d}$ & & 100 & & 100 & 100 & - & + \\
\hline Nitrate reductase & 100 & $82^{e}$ & & & 100 & 58 & + & + \\
\hline \multicolumn{9}{|l|}{ Growth at/in/on: } \\
\hline $10 \mathrm{C}(\mathrm{YD})$ & $6^{d}$ & 100 & 100 & 97 & 100 & 94 & - & + \\
\hline $45 \mathrm{C}(\mathrm{YD})$ & 0 & 46 & 53 & 11 & 14 & 66 & - & - \\
\hline Lysozyme broth & $9^{d}$ & & 59 & & 28 & 94 & + & + \\
\hline $5 \% \mathrm{NaCl}(\mathrm{YD})$ & $6^{d}$ & & 100 & & 100 & 83 & - & + \\
\hline Adenine agar & $6^{d}$ & & 100 & & 100 & 100 & + & + \\
\hline \multicolumn{9}{|l|}{ Acid from: } \\
\hline Adonitol & 0 & & 0 & & 0 & 0 & - & - \\
\hline Arabinose & 0 & 8 & & 0 & & 0 & - & - \\
\hline Cellobiose & 0 & & 6 & & 0 & 0 & - & - \\
\hline Dulcitol & 0 & 0 & & 0 & & 0 & - & - \\
\hline Ery thritol & 0 & & 12 & & 0 & 0 & - & - \\
\hline Fructose & 100 & & 100 & & 43 & 100 & + & + \\
\hline Galactose & 0 & & 6 & & 0 & 17 & + & + \\
\hline Glucose & 100 & 99 & & 100 & & 100 & + & + \\
\hline Glycerol & 100 & & 94 & & 57 & 100 & + & + \\
\hline Inositol & $92^{d}$ & 21 & & 0 & & 75 & + & - \\
\hline Lactose & 0 & 0 & & 0 & & 0 & - & - \\
\hline Maltose & 100 & $27^{e}$ & 35 & & 14 & 8 & - & - \\
\hline Mannitol & 100 & 99 & 100 & 0 & 0 & 100 & + & + \\
\hline Mannose & 100 & 99 & & 61 & & 100 & + & - \\
\hline Melibiose & 0 & & 0 & & 0 & 0 & - & - \\
\hline$\alpha$-Methyl-D-glucoside & 0 & 0 & & 0 & & 0 & - & - \\
\hline Raffinose & 0 & 0 & & 0 & & 0 & - & - \\
\hline Rhamnose & $92^{d}$ & 9 & & 0 & & 0 & + & - \\
\hline Salicin & 100 & & 29 & & 0 & 25 & -- & -- \\
\hline Sorbitol & 0 & 100 & 100 & 0 & 0 & 100 & - & + \\
\hline Sucrose & 100 & & 100 & & 29 & 100 & - & - \\
\hline Trehalose & 100 & 97 & & 24 & & 92 & + & + \\
\hline Xylose & 0 & & 41 & & 0 & 42 & + & - \\
\hline$\beta$-Methyl-D-xyloside & 0 & & 0 & & 0 & 0 & - & - \\
\hline \multicolumn{9}{|l|}{ Utilization of: } \\
\hline Acetate & 100 & & 100 & & 100 & 100 & + & + \\
\hline Benzoate & 0 & 70 & & 19 & & 83 & - & - \\
\hline Citrate & 0 & 90 & & 8 & & 100 & + & $\ldots$ \\
\hline Lactate & 100 & 100 & & 100 & & 100 & + & $\ldots$ \\
\hline Malate & 100 & 99 & & 94 & & 100 & + & + \\
\hline Oxalate & 0 & 0 & & 0 & & 0 & - & - \\
\hline Propionate & 100 & & 100 & & 100 & 100 & + & + \\
\hline Pyruvate & 100 & & 100 & & 100 & 100 & + & + \\
\hline Succinate & 100 & 100 & & 97 & & 100 & + & + \\
\hline Tartrate & 0 & & 12 & & 0 & 0 & - & - \\
\hline \multicolumn{9}{|l|}{ Survival: } \\
\hline $50 \mathrm{C} / 8 \mathrm{~h}$ & 0 & & 82 & & 86 & 92 & $\mathrm{ND}^{f}$ & $\mathrm{ND}$ \\
\hline
\end{tabular}

a R. E. Gordon (6).

$b$ Run by authors.

$c$ Percent positive; w, weak.

$d$ Reactions of type strain (ATCC 27808): Starch hydrolysis -; phosphatase production +; growth at $10 \mathrm{C}-$; growth in/on: lysozyme broth _-, $5 \% \mathrm{NaCl}$ (YD) - - , adenine agar - -; acid from: inositol +, rhamnose + .

$\boldsymbol{e}$ Based on tests of 60 strains (Gordon and Mihm, 1957).

$f$ ND, Not determined. 


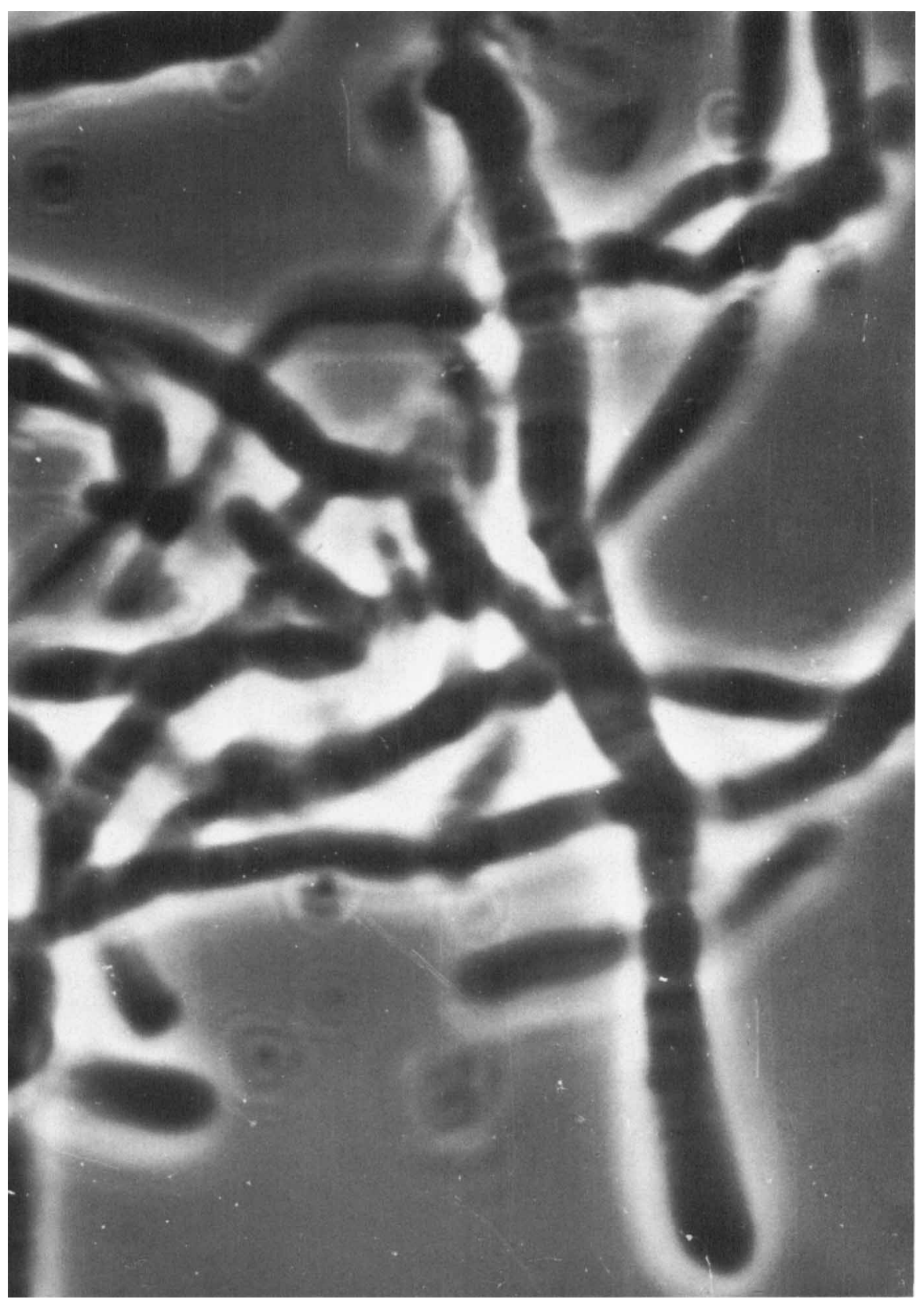

FIG. 1. Phase contrast, oil immersion objective, $\times 8,000$. Strain Se 85 grown 1 week in YD broth in shaken culture at $28 \mathrm{C}$.

tested eight strains of the organism described here in guinea pigs and mice and found them to be nonpathogenic (personal communication).

When the physiology of these sewage strains was compared with that of strains of $N$. asteroides, $N$. brasiliensis, and $N$. caviae, it was found to differ as indicated in Table 2. These strains were closest to $N$. ("Mycobacterium") rhodochrous, strains of which are also isolated occasionally from foams. A comparison of these two taxa, along with the reactions of strains of $N$. rhodochrous isolated from sewage, $N$. vaccinii 3500 , and $N$. carnea 3419 , are presented in Table 3 . 


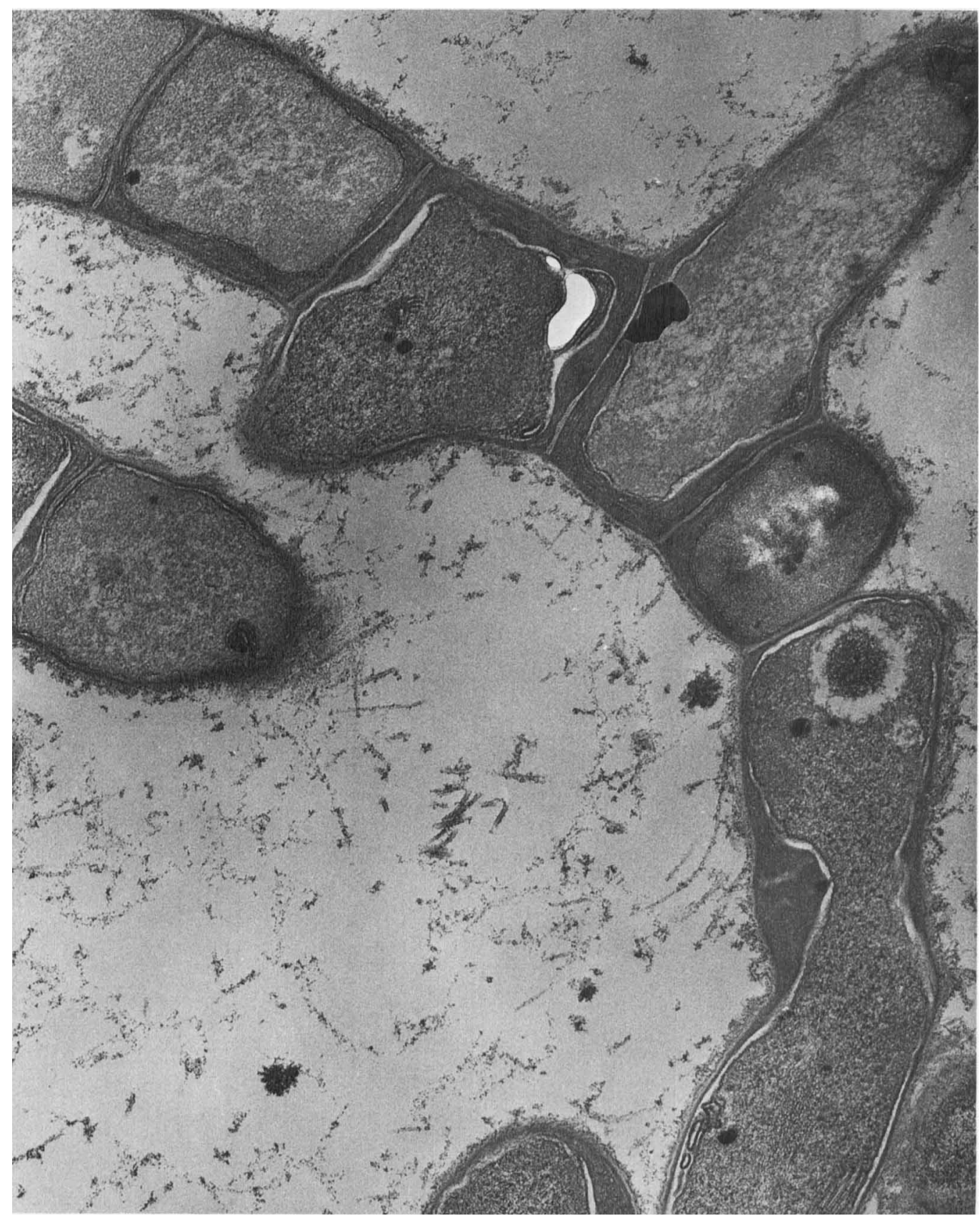

FIG. 2. Electron micrograph. Section through hyphae of strain Se $149 B$ grown 1 week on YD agar. $\times 37,000$.

The principal characteristics differentiating the new organism from $N$. rhodochrous are the following: nocardomycolic acid type, hydrolysis of tyrosine, growth at $10 \mathrm{C}$, growth on adenine and on $5 \% \mathrm{NaCl}$, acid from inositol, maltose, rhamnose, salicin, and sorbitol, utiliza- tion of benzoate and citrate, and survival at 50 $\mathrm{C}$ for $8 \mathrm{~h}$. The principal differences between the new organism and Gordon's (6) rhodochrous -related Nocardia sp. (which she placed in $M$. rhodochrous) are: nocardomycolic acid type, hydrolysis of adenine, growth at $10 \mathrm{C}$, growth 


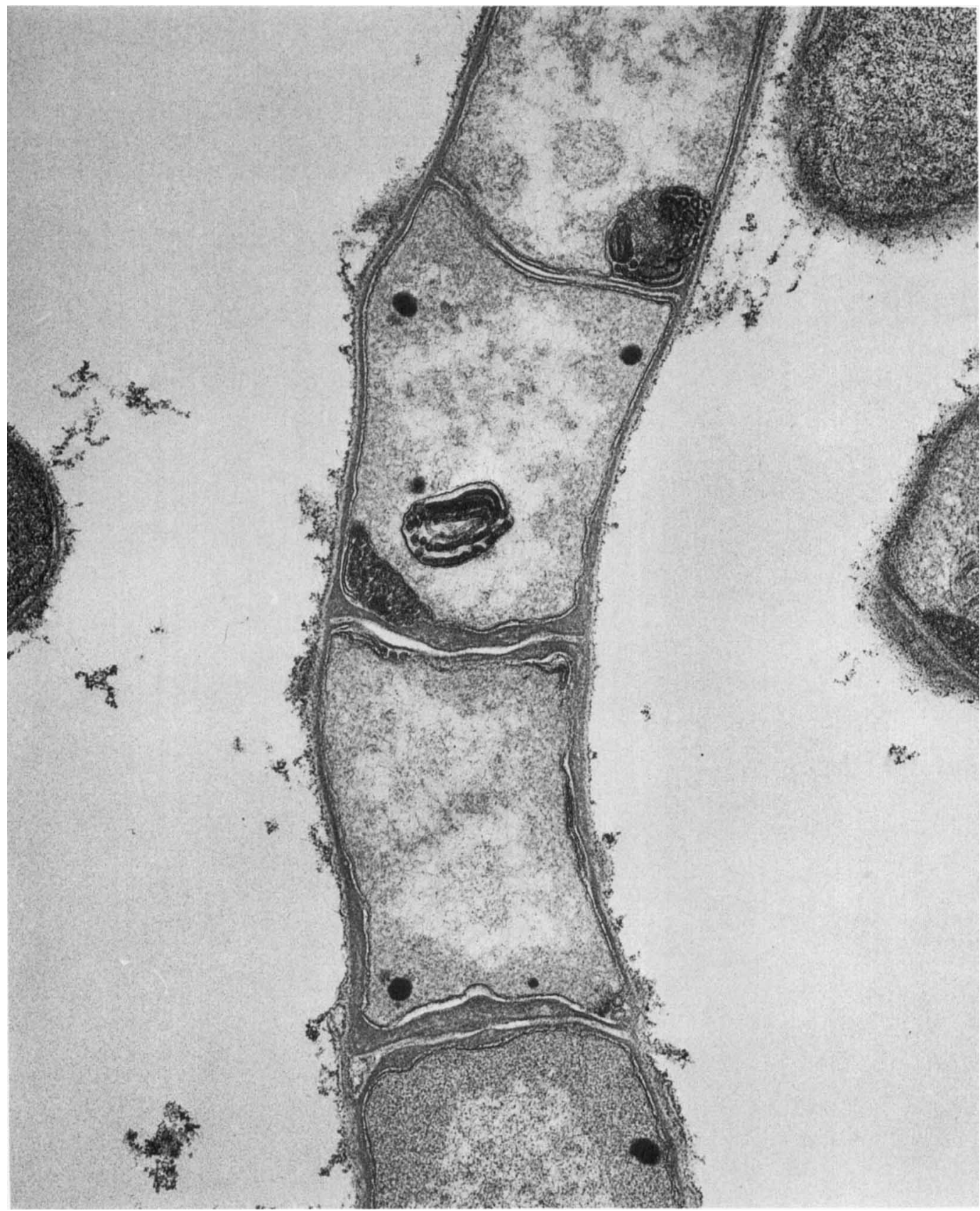

FIG. 3. Same as Fig. 2. ×52,500.

on adenine and $5 \% \mathrm{NaCl}$, acid from fructose, maltose, mannitol, rhamnose, salicin, sucrose, and trehalose, and survival at $50 \mathrm{C}$.

The new organism also differs from the Russian N. ucrainica (14) by eleven characters: acid from galactose, lactose, $\alpha$-methyl-D- glycoside, raffinose, rhamnose, and xylose, utilization of citrate, decomposition of tyrosine and casein, and growth on $5 \% \mathrm{NaCl}$.

Ruth E. Gordon of our Institute has informed us (personal communication, 1973) that she has no named strains of Nocardia in 


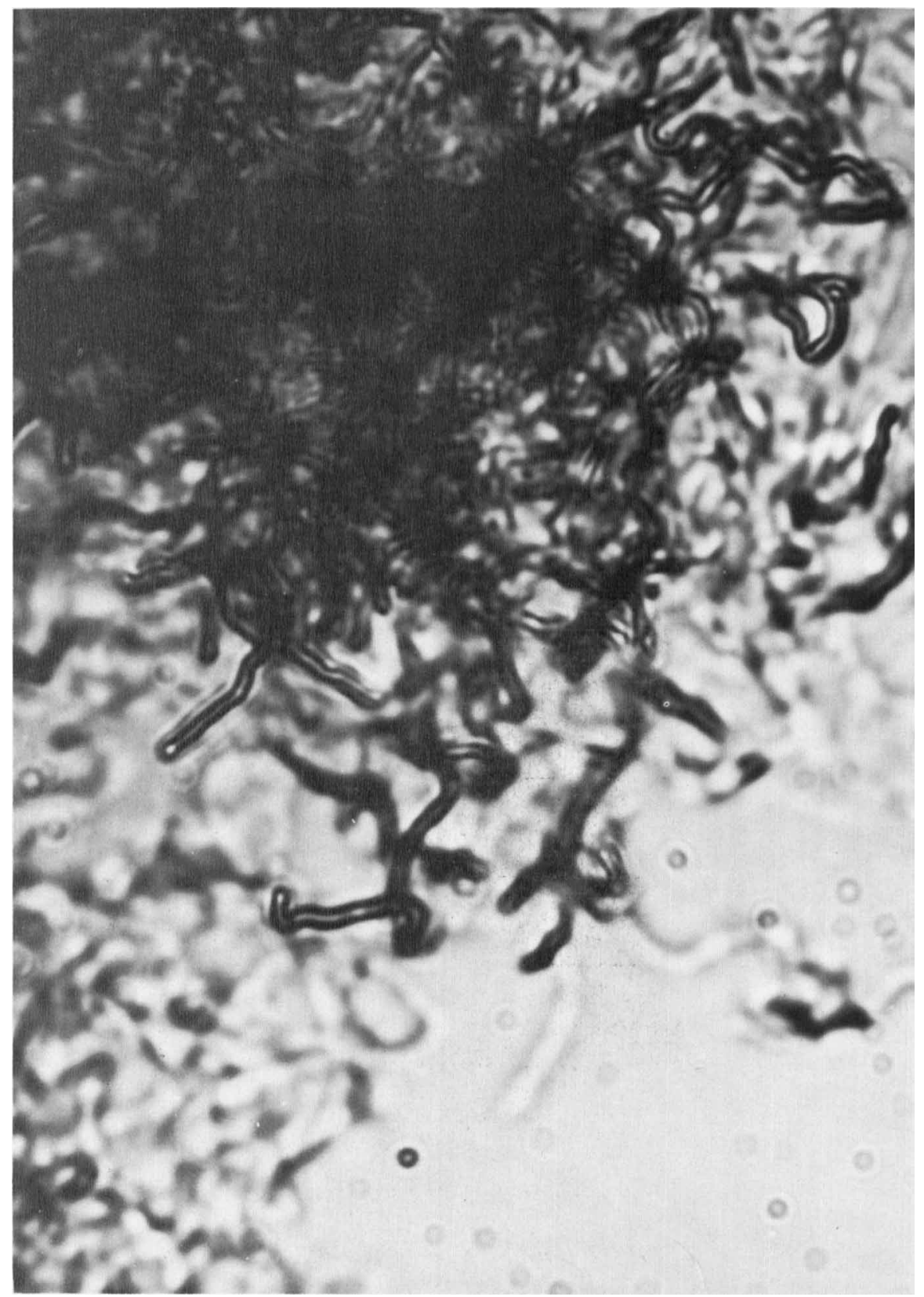

FIG. 4. Bright-field, high-dry objective. Strain Se 6 growing on Bennett's agar. $\times 2,000$.

the IMRU collection having the same pattern of physiological reactions as our organism.

On the basis of the overall evidence, we regard the organism described here as a new species, for which we propose the name Nocardia amarae. (Gr. n. $\alpha \mu \alpha \dot{\alpha} \rho \alpha$, sewage duct; M.L. gen. n. amarae of a sewage duct.)
Description of Nocardia amarae sp. nov.: substrate mycelium. Moderately branching vegetative hyphae are variable in diameter but about $1 \mu \mathrm{m}$ wide; the hyphae penetrate and grow into the agar medium; they do not fragment in undisturbed cultures; secondary branching is rare to absent; the colony edge is 
filamentous, never entire. Many strains on first isolation show banded hyphae (Fig. 1). This characteristic is lost on prolonged cultivation but can be observed in hyphae in sewage. Hyphae are often irregularly swollen and break up into coryneform elements when mounted in water. Sections through banded hyphae show numerous cross walls, cells with irregularly thickened, laminated walls, empty spaces, numerous mesosomes and, within the same hypha, cells containing cytoplasm of varying electron opacities (Fig. 2 and 3).

Aerial mycelium. Aerial mycelium is not visible to the naked eye. Short, branched, and unbranched aerial hyphae may be seen by the use of a microscope. No specialized morphological structures have been noted (Fig. 4).

Appearance on various media. Growth of all strains on various media is always tan, convoluted, and lacking macroscopically visible aerial hyphae. A small amount of brown-black, soluble pigment is produced on YCZ agar by some strains.

Staining characteristics. The filaments are gram-positive and only partially acid-fast, if at all.

Physiological and chemical characteristics. Catalase-positive. Attacks glucose oxidatively. Cell wall of type IV. Contains nocardomycolic acids having an unsaturated $\alpha$ branch. Grows at 23 to $37 \mathrm{C}$.

Esculin and urea hydrolyzed. No hydrolysis of casein, xanthine, hypoxanthine, tyrosine, adenine, or gelatin. Starch was weakly hydrolyzed $(86 \%$ of the strains studied were positive). Nitrate reductase produced. Phosphatase produced $(83 \%)$. No growth at $10(94 \%)$ or $45 \mathrm{C}$ or on $5 \% \mathrm{NaCl}$. No growth in lysozyme broth (91\%) or on adenine agar $(94 \%)$. Acetate, lactate, malate, propionate, pyruvate, and succinate utilized. Benzoate, citrate, oxalate, and tartrate not utilizéd. Acid from fructose, glucose, glycerol, inositol (92\%), maltose, mannitol, mannose, rhamnose $(92 \%)$, salicin, sucrose, and trehalose. No acid from adonitol, arabinose, cellobiose, dulcitol, galactose, lactose, melibiose, $\alpha$-methyl-D-glucoside, raffinose, sorbitol, xylose, $\beta$-methyl D-xyloside. No survival at $50 \mathrm{C}$ for $8 \mathrm{~h}$.

Type strain: Se6 (= ATCC 27808; = IMRU W3960).

Reactions of the type strain are given as a footnote to Table 3 .

\section{ACKNOWLEDGMENTS}

This work was supported by Environmental Protection Agency grant R-802003 and National Science Foundation grant GB 18705.
We wish to thank Ruth E. Gordon for providing some of the cultures included in this study, B. K. Ghosh for advice on electron microscopy, N. Hess for embedding and sectioning the materials observed with the electron microscope, and Eva Fekete and Magda Gagliardi for technical assistance.

\section{LITERATURE CITED}

1. Barber, M., and S. W. A. Kuper. 1951. Identification of Staphylococcus pyogenes by the phosphatase reaction. J. Pathol. Bacteriol. 63:65-68.

2. Cooke, W. B., and W. O. Pipes. 1970. The occurrence of fungi in activated sludge. Mycopathol. Mycol. Appl. 40:249-270.

3. Cyrus, Z., and A. Sladká. 1970. Several interesting organisms present in activated sludge. Hydrobiologia 35:383-396.

4. Goodfellow, M. 1971. Numerical taxonomy of some nocardioform bacteria. J. Gen. Microbiol. 69:33-80.

5. Gordon, R. E. 1966. Some criteria for the recognition of Nocardia madurae. J. Gen. Microbiol. 45:355-364.

6. Gordon, R. E. 1966. Some strains in search of a genus Corynebacterium, Mycobacterium, Nocardia or what? J. Gen. Microbiol. 43:329-343.

7. Gordon, R. E. 1967. The taxonomy of soil bacteria, p. 293-321. In T. Gray, R. G. Parkinson, and B. Parkinson (ed.), The ecology of soil bacteria. Liverpool University Press.

8. Gordon, R. E., and A. C. Horan. 1968. Nocardia dassonvillei, a macroscopic replica of Streptomyces griseus. J. Gen. Microbiol. 50:235-240.

9. Gordon, R. E., and J. M. Mihm. 1957. A comparative study of some strains received as nocardiae. J. Bacteriol. 73:15-27.

10. Gordon, R. E., and J. M. Mihm. 1962. Identification of Nocardia caviae (Erikson) nov. comb. Ann. N.Y. Acad. Sci. 98:628-636.

11. Gordon, R. E., and M. M. Smith. 1953. Rapidly growing, acid fast bacteria. I. Species descriptions of Mycobacterium phlei Lehmann and Neumann and Mycobacterium smegnatis (Trevisan) Lehmann and Neumann. J. Bacteriol. 66:41-48.

12. Higgins, M. L., and M. P. Lechevalier. 1969. Poorly lytic bacteriophage from Dactylosporangium thailandensis. J. Virol. 3:210-216.

13. Ioneda, T., E. Lederer, and J. Rozanis. 1970. Sur la structure des diesters de tréhalose ("cord factors") produits par Nocardia asteroides et Nocardia rhodochrous. Chem. Phys. Lipids 4: 375-392.

14. Krasnikov, E. I., A. Nesterenko, V. A. Romanovskaya, and S. A. Kasumova. 1971. Microorganisms of the genera Nocardia Trevisan and Mycobacterium Lehmann and Neumann which utilize natural and individual gaseous hydrocarbons. Microbiology U.S.S.R. 40:240-246.

15. Lechevalier, M. P. 1968. Identificaiton of aerobic actinomycetes of clinical importance. J. Lab. Clin. Med. 71:934-944.

16. Lechevalier, M. P., A. C. Horan, and H. Lechevalier. 1971. Lipid composition in the classifica- 
tion of nocardiae and mycobacteria. J. Bacteriol. 105:313-318.

17. Lechevalier, H. A., and M. P. Lechevalier. 1970. A critical evaluation of the genera of aerobic actinomycetes, p. 393-405. In H. Prauser (ed.), The actinomycetales. Fischer. Jena.

18. Lechevalier, M. P., H. A. Lechevalier, and C. E. Heintz. 1973. Morphological and chemical nature of the sclerotia of Chainia olivacea Thirumalachar and Sukapure of the Order Actinomy. cetales. Int. J. Syst. Bacteriol. 23:157-170.

19. Lechevalier, M. P., H. Lechevalier, and A. C. Horan. 1973. Chemical characteristics and classification of nocardiae. Can. J. Microbiol. 19:965-972.

20. McKinney, R. E., and M. P. Horwood. 1952.
Floc-producing bacteria. Sewage Ind. Wastes 24: 117-123.

21. Mohanrao, G. J., and R. E. McKinney. 1962. A study of the biochemical characteristics of quaternary carbon compounds. Int. J. Air Water Pollut. 6:153-168.

22. Suput, J., M. P. Lechevalier, and H. A. Lechevalier. 1967. Chemical composition of variants of aerobic actinomycetes. Appl. Microbiol. 15:13561361.

23. Waksman, S. A. 1950. The actinomycetes. Chronica Bontanica. Waltham, Mass.

24. Wells, W. N., and M. T. Garrett. 1971. Getting the most from an activated sludge plant. Pub. Works, May: 63-68. 